BUDGETING : Journal of Business, Management and Accounting

Volume 1, Nomor 2, Juni 2020

e-ISSN: $2715-2480$

p-ISSN: 2715-1913

DOI : https://doi.org/10.31539/budgeting.vli2.805

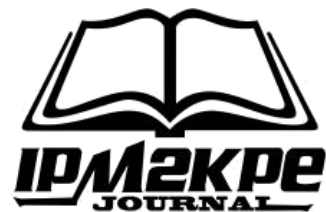

\title{
ANALISIS PROFITABILITAS, SOLVABILITAS DAN UKURAN PERUSAHAAN YANG MENYEBABKAN AUDIT DELAY
}

\author{
Lala Febby Ardiany ${ }^{1}$, R. Deni Muhammad Danial ${ }^{2}$, Dicky Jhoansyah ${ }^{3}$ \\ Universitas Muhammadiyah Sukabumi ${ }^{1,2 ; 3}$ \\ ardiany05@yahoo.com ${ }^{1}$
}

\begin{abstract}
ABSTRAK
Tujuan penelitian ini adalah untuk mengetahui rasio profitabilitas, solvabilitas dan ukuran perusahaan apakah mempengaruhi terjadinya Audit Delay pada PT Apexindo Pratama Duta Tbk yang terdaftar di BEI periode 2015-2017. metode analisis yang digunakan dalam penelitian ini adalah metode deskriptif-asosiatif. Data yang digunakan dalam penelitian ini adalah data sekunder dari laporan keuangan perusahaan. Hasil penelitian menunjukan nilai Nagelkerke $R$ Square adalah 0,672. Nilai tersebut menunjukan kemampuan variabel independen (profitabilitas, solvabilitas dan ukuran perusahaan) dalam menjelaskan variabel dependen (Audit Delay) adalah 67,2\% dan sisanya sebesar 32,8\% terdapat faktor lain di luar model yang menjelaskan variabel dependen. Dan hasil dari pada Omnibus Test of Model Coefficients dengan nilai 0,329 yang artinya lebih besar dari 0,05 maka variabel profitabilitas, solvabilitas dan ukuran perusahaan secara bersama-sama tidak mempengaruhi model (Audit Delay) perusahaan. Kesimpulan, variabel profitabilitas, solvabilitas dan ukuran perusahaan tidak mempengaruhi dan menyebabkan Audit Delay pada PT Apexindo Pratama Duta Tbk.
\end{abstract}

Kata Kunci : Audit Delay, Rasio Profitabilitas, Rasio Solvabilitas, Ukuran Perusahaan.

\begin{abstract}
The purpose of this study is to determine the ratio of profitability, solvency and size of the company whether it affects the Audit Delay on PT Apexindo Pratama Duta Tbk listed on the Stock Exchange in the 2015-2017 period. the analytical method used in this research is descriptive-associative method. The data used in this study are secondary data from the company's financial statements. The results showed the value of Nagelkerke $R$ Square was 0.672. This value shows the ability of independent variables (profitability, solvency and company size) in explaining the dependent variable (Audit Delay) is $67.2 \%$ and the remaining $32.8 \%$ there are other factors outside the model that explain the dependent variable. And the results of the Omnibus Test of Model Coefficients with a value of 0.329, which means greater than 0.05, the profitability, solvency and size of the company variables together do not affect the company's model (Audit Delay). In conclusion, profitability, solvency and company size variables do not affect and cause Audit Delay at PT Apexindo Pratama Duta Tbk.
\end{abstract}

Keywords: Audit Delay, Company's Measurement, Profitability Ratio Solvability Ratio, 


\section{PENDAHULUAN}

Seiring berkembangnya zaman, dunia bisnis kini berkembang dengan pesat di Indonesia dan menimbulkan persaingan yang ketat. Saat ini banyak sekali gedunggedung tinggi milik perusahaan yang mencoba memperluas pangsa pasarnya dan berlomba-lomba menjadi yang terbaik. Memperluas pangsa pasar bisa disebut juga dengan memperbesar bisnis.

Dalam memperluas bisnisnya, tentunya sebuah perusahaan membutuhkan modal yang lebih banyak lagi dan juga sebuah perusahaan butuh citra demi memperluas pangsa pasar. Salah satunya yaitu modal. Modal merupakan fondasi awal sebuah perusahaan. Modal yang didapatkan dari pemilik perusahaan, kadang belum mencukupi sehingga membutuhkan tambahan modal dari luar. Penambahan modal dari luar ini dengan cara perusahaan bisa melepaskan sahamnya atau diperdagangkan kepada masyarakat. Dengan melepaskan sahamnya ini maka perusahaan tersebut yang awal mulanya tertutup menjadi perusahaan yang Go Public atau perusahaan terbuka. Setelah berubah menjadi perusahaan terbuka, maka nama perusahaan tersebut harus di tambahkan TBK (terbuka).

Perusahaan terbuka artinya perusahaan itu menjadi milik masyarakat yang memiliki saham di perusahaan tersebut, dan perusahaan harus lebih transparan. Transparan ini adalah bentuk tanggung jawab kepada pemilik saham perusahaan tersebut. Selain itu juga transparansi ini dapat menimbulkan kepercayaan antara pemilik saham kepada perusahaan, atau sebagai bahan pertimbangan pemilik saham. Transparansi ini ialah dengan memaparkan laporan keuangan tahunan yang telah di audit yang independen.

Kewajiban sebuah perusahaan yang sudah menjadi Go Public ini adalah mempublikasikan laporan keuangan perusahaan yang bisa dilihat oleh para investor atau masyarakat. Akan tetapi sebelum dipublikasikan kepada investor atau masyarakat, seperti yang sudah disebutkan laporan keuangan tersebut harus sudah di audit oleh auditor yang independen.

Maksud independen ini, auditor yang akan mengaudit tidak memihak atau subjektif. Tidak ada hubungan persaudaraan, pertemanan, atau keluarga sehingga laporan keuangan yang akan di audit memungkinkan tidak ada yang di tutup-tutupi dan 
bersifat objektif. Selain itu, yang terpenting laporan keuangan sudah disertai dengan opini auditor.

Opini ini menjadikan tanda bahwa laporan keuagan tersebut sudah layak, atau telah tersusun sebagaimana mestinya. Maksudnya apakah keuangannya, hasil usaha, maupun kas sudah dituliskan secara wajar. Selain opini juga laporan keuangan ini sebagai cara dalam menyampaikan informasi maupun kinerja sebuah perusahaan. Jika laporan keuangan sebuah perusahaan belum di audit atau tidak adanya opini dari auditor apakah laporan itu sudah disajikan dengan wajar, maka laporan keuangan itu perlu diragukan walaupun laporan itu dibuat oleh manajemen perusahaan karena laporan tersebut belum diketahui apakah laporannya tidak ada penyimpangan atau kesalahan.

Agar laporan keuangan perusahaan tersebut wajar, auditor harus mengumpulkan bukti-bukti yang mendukung proses audit misalnya bukti-bukti transaksi. Auditor juga harus sangat berhati-hati dalam mengaudit agar tidak terjadi kesalahan. Selama proses pengauditan ini disebut dengan Audit Delay. Proses ini terjadi dari tanggal pencatatan penutupan buku (31 Desember) sampai dengan tanggal dipublikasikannya laporan yang telah di audit. Sedangkan waktu yang diberikan oleh OJK (Otoritas Jasa Keuangan) untuk menyampaikan laporan keuangan perusahaan yang telah di audit paling lambat pada akhir bulan ke empat terhitung sejak dikeluarkannya laporan keuangan tahunan atau tanggal tutup buku (31 Desember).

Sebagaimana lampiran yang dikeluarkan oleh OJK (Otoritas Jasa Keuangan) dengan Nomor 29/POJK.04/2016 menyebutkan bahwa emiten atau perusahaan publik wajib menyampaikan laporan tahunan kepada OJK (Otoritas Jasa Keuangan) paling lambat pada akhir bulan ke empat setelahtahun buku berakhir.

Menurut Ashton et al (1987) dalam Malinda Dwi Apriliane (2015) faktor yang mempengaruhi Audit Delay bisa disebabkan dari faktor internal maupun eksternal. Faktor internal ini ialah total pendapatan, tipe industri, kompleksitas laporan keuangan, kompleksitas data elektronik, laba dilihat dari total aset, umur perusahaan, pos-pos luar biasa, laba, kompleksitas operasi perusahaan dan ukuran perusahaan. Sedangkan faktor eksternal ialah opini audit, reputasi auditor, dan kualitas auditor.

Dari faktor-faktor yang mempengaruhi Audit Delay di atas, peneliti mengambil 2 faktor internal dari faktor-faktor yang telah disebutkan yaitu profitabilitas, dan ukuran perusahaan. Di dalam laporan keuangan tentunya terdapat neraca dan laporan laba rugi 
yang mejadi salah satu komponen kondisi suatu perusahaan. Bagaimana kemampuan sebuah perusahaan dapat memperoleh laba atau dengan kata lain yaitu profitabilitas.

Profitabilitas dapat menggabarkan bagaimana perusahaan bisa menghasilkan laba dengan modal yang dimiliki. Jika sebuah perusahaan dapat menghasilkan laba, maka perusahaan tersebut bisa menarik perhatian para investor untuk menanamkan dananya sebab perusahaan terbuka atau Go Public selalu diawasi oleh para investor. Para investor biasanya cermat dalam meneliti profit perusahaan.

Dengan perusahaan mendapatkan laba, otomatis prospek perusahaan tersebut bagus. Semakin besar persentase dari profitabilitas yang didapat, maka semakin besar laba yang didapat oleh sebuah perusahaan. Selain bagaimana cara sebuah perusahaan memperoleh laba, setiap perusahaan pasti terkait dengan yang namanya hutang yang harus dibayarkan.

Solvabilitas ini bagaimana sebuah perusahaan dalam memenuhi kewajibankewajibannya baik dalam jangka pendek maupun jangka panjang. Jika nilai profitabilitas rendah maka dalam menganalisa laporan keuangan harus lebih berhati-hati dan membutuhkan waktu yang lebih atau sebaliknya. Sama halnya dengan jika nilai solvabilitas perusahaan besar auditor juga harus berhati-hati dalam menganalisa keuangan, karena nilai beban yang didapat perusahaan besar juga sebaliknya.

Sama halnya dengan profitabilitas yang telah disebutkan, jika nilai pendapatan atau aktiva di atas seratus milyar, maka perusahaan tersebut termasuk kepada perusahaan besar dan perusahaan tidak akan menunda pengauditan karena pendapatan yang besar adalah sebuah berita baik dan yang dinantikan oleh para investor. Sebagaimana berdasarkan peraturan OJK (Otoritas Jasa Keuangan) Nomor 54/POJK.04/2017 menyebutkan bahwa emiten skala kecil adalah emiten berbentuk badan hukum yang didirikan di Indonesia yang memiliki total aset atau istilah lain yang setara, tidak lebih dari Rp. 50.000.000.000,00 (lima puluh miliar rupiah), dan emiten skala menengah adalah emiten bebentuk badan hukum yang didirikan di Indonesia yang memiliki total aset atau istilah lain yang setara, di atas Rp. 50.000.000.000,00 (lima puluh miliar rupiah) sampai dengan Rp. 250.000.000.000,00 (dua ratus lima puluh miliar rupiah), maka perusahaan besar memiliki total aset atau istilah lain yang setara, di atas Rp. 250.000.000.000,00 (dua ratus lima puluh miliar rupiah). 
PT. Apexindo Pratama Duta Tbk merupakan satu-satunya perusahaan Indonesia yang bergerak di bidang pengeboran lepas pantai dan pengeboran darat untuk industri minyak, gas, panas bumi dan coal bed methane. Namun berdasarkan hasil penjajakan, PT. Apexindo Pratama Duta Tbk ini mengalami keterlambatan pengauditan laporan keuangan setiap tahunnya dimulai dari tahun 2013-2017. Berikut data perusahaan PT. Apexindo Pratama Duta Tbk yang dilihat dari tanggal laporan keuangan tahunan yang telah di audit. Lebih jelas dapat dilihat Pada gambar 1. di bawah ini

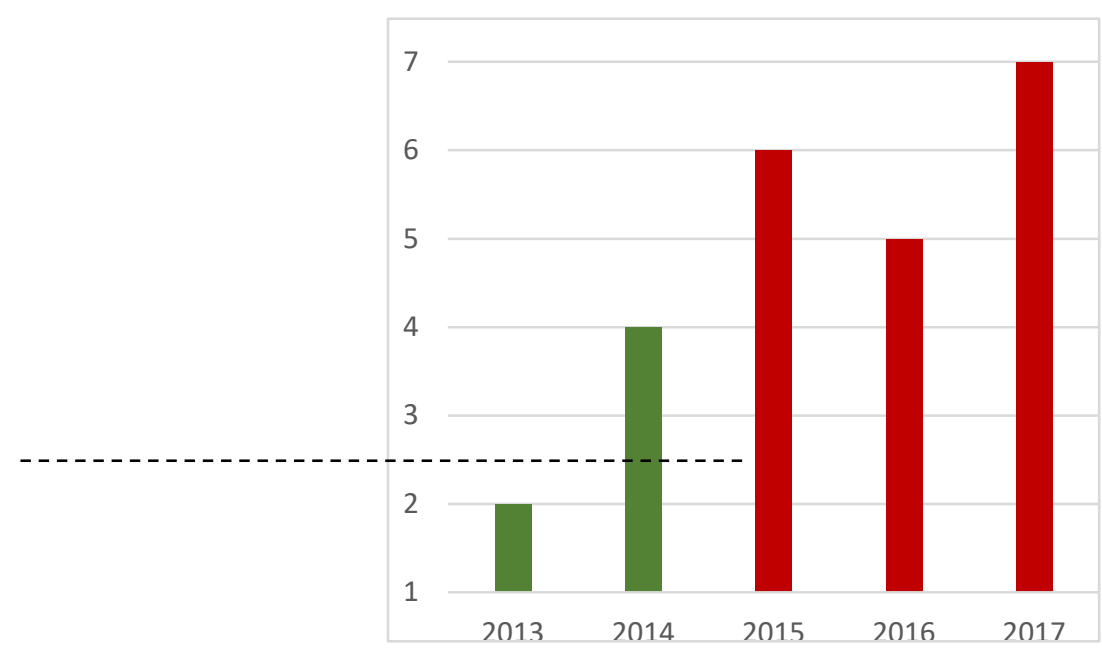

Sumber: www.idx.co.id Data diolah (2019)

Gambar 1. Bulan Pengauditan Laporan Keuangan Tahunan

PT. Apexindo Pratama Duta Tbk pada Tahun 2013-2017

Berdasarkan gambar dapat diketahui bahwa pengauditan laporan keuangan tahunan pada PT. Apexindo Pratama Duta. Tbk yang dilihat pada tanggal dikeluarkannya opini auditor cenderung mengalami keterlambatan setiap tahunnya. Hanya pada tahun 2013 dan 2014 yang tidak mengalami keterlambatan pengauditan laporan keuangan tahunan. Sisanya dari tahun 2015-2017 PT.Apexindo Pratama Duta Tbk melewati batas garis putus-putus yang berarti perusahaan tersebut sudah melewati batas waktu pengauditan laporan keuangan yang diberikan oleh OJK (Otoritas Jasa Keuangan) yaitu pada akhir bulan ke empat.

\section{KAJIAN TEORI}

\section{Audit Delay}

Audit Delay atau keterlambatan mempublikasikan laporan keuangan tahunan bisa terjadi karena lamanya proses pengauditan sampai melebihi batas waktu yang telah 
ditentukan oleh OJK. Hal ini tentu tercantum dalam peraturan Nomor 29/POJK.04/2016 pasal 7 ayat 1 disebtutkan bahwa "emiten atau perusahaan publik wajib menyampaikan laporan tahunan kepada OJK (Otoritas Jasa Keuangan) paling lambat pada akhir bulan ke 4 setelah tahun buku berakhir."

Dyer dan McHugh (1975) dalam Respati (2004) terdapat tiga keterlambatan dalam penyampaian laporan keuangan, antara lain: 1) Preliminary lag, yaitu interval jumlah hari antara tanggal berakhirnya tahun buku sampai dengan tanggal diterimanya laporan keuangan pendahuluan oleh bursa; 2) Auditor's signature lag, yaitu interval jumlah hari antara tanggal berakhirnya tahun buku sampai dengan tanggal laporan auditor ditandatangani; 3) Total lag, yaitu interval jumlah hari antara tanggal berakhirnya tahun buku sampai dengan tanggal penerimaan laporan keuangan tahunan dipublikasikan di bursa.

\section{Profitabilitas}

Rasio profitabilitas dapat atau biasa digunakan untuk menganalisis laporan keuangan. Para pemegang saham tentunya bisa menggunakannya untuk menganalisis maupun sebagai bahan pertimbangan. Menurut Astuti (2004) rasio profitabilitas adalah: "suatu kemampuan perusahaan untuk menghasilkan laba. Satu-satunya ukuran profitabilitas yang paling penting adalah laba bersih. Para investor da kreditur sangat berkepentingan dalam mengevaluasi kemampuan perusahaan menghasilkan laba saat ini maupun di masa yang akan datang." Rumus yang digunakan dalam penelitian ini adalah Return On assets atau Return On Investment menunjukan kemampuan perusahaan menghasilkan laba dari aktiva yang dipergunakan.

$$
\text { Return On Assets }=\frac{\text { Laba Bersih }}{\text { Jumlah Aset }}
$$

\section{Solvabilitas}

Solvabilitas adalah dimana perusahaan mampu menutupi semua kewajibannya baik jangka pendek maupun jangka panjang, dan jika perusahaan ini mampu disebut dengan solvabel. Menurut solvabilitas menurut S. Munawir (2002) mengataka "Solvabilitas adalah perunjuk kemampuan perusahaan untuk memenuhi kewajiban keuangannya apabila perusahaan tersebut dilikuidasi, baik keuangan jangka pendek maupun jangka panjang." Rumus solvabilitas yang digunakan dalam penelitian ini 
adalah (Debt to Assets Ratio) DAR Rasio hutang yang digunakan untuk mengukur perbandingan antara total hutang dengan total aktiva"

$$
D A R=\frac{\text { Total Hutang }}{\text { Total Aset }}
$$

\section{Ukuran Perusahaan}

Sebagaimana secara umum ukuran berkaitan dengan besar atau kecil.

Menurut Brigham \& Houston (2010) ukuran perusahaan adalah "Ukuran perusahaan merupakan ukuran besar kecilnya sebuah perusahaan yang ditunjukan atau dinilai oleh total asset, total penjualan, jumlah laba, beban pajak dan lain-lain.

Sebagaimana berdasarkan peraturan OJK (Otoritas Jasa Keuangan) Nomor 54/POJK.04/2017 menyebutkan bahwa emiten skala kecil adalah emiten berbentuk badan hukum yang didirikan di Indonesia yang memiliki total aset atau istilah lain yang setara, tidak lebih dari Rp. 50.000.000.000,00 (lima puluh miliar rupiah), dan emiten skala menengah adalah emiten bebentuk badan hukum yang didirikan di Indonesia yang memiliki total aset atau istilah lain yang setara, di atas Rp. 50.000.000.000,00 (lima puluh miliar rupiah) sampai dengan Rp. 250.000.000.000,00 (dua ratus lima puluh miliar rupiah), maka perusahaan besar memiliki total aset atau istilah lain yang setara, di atas Rp. 250.000.000.000,00 (dua ratus lima puluh miliar rupiah).

Menurut Erin Juniati (2016) Ukuran perusahaan berpengaruh terhadap keterlambatan penyampaian laporan keuangan dengan signifikansi sebesar 0,04\% . Profitabilitas tidak berpengaruh terhadap keterlambatan penyampaian laporan keuangan dengan signifikansi sebesar $0,3 \%$. Solvabilitas tidak berpengaruh terhadap keterlambatan penyampaian laporan keuangan dengan signifikansi sebesar 0,24.

\section{METODE PENELITIAN}

Metode yang digunakan dalam penelitian ini adalah metode deskriptif asosiatif. Penelitian ini terdiri dari X1 profitabilitas, X2 Solvabilitas, X3 Ukuran Perusahaan sebagai variabel independen dan Y ialah Audit Delay sebagai variabel dependen. Teknik pengumpulan data pada penelitian ini, peneliti menggunakan data sekunder, karena data yang diperoleh peneliti dengan mengunduh data laporan keuangan perusahaan dari situs www.idx.co.id Adapun teknik pengumpulan data untuk mendukung penelitian ini juga menggunakan data sekunder, studi kepustakaan, dokumentasi perusahaan. Adapun 
popolasi pada penelitian ini adalah laporan keuangan tahunan PT. Apexindo Pratama Duta Tbk dan sampel pada penelitian ini adalah laporan keuangan PT. Apexindo Pratama Duta Tbk periode 2013-2017. Teknik analisa data menggunakan analisis regresi logistik yang sebelumya dihitung menggunakan rasio profitabilitas, solvabilitas dan ukuran perusahaan yang dapat dilihat pada laporan keuangan perusahaan.

\section{Omnibus Test of Model Coeficient}

Omnibus ini adalah uji signifikansi secara simultan atau brsama-sama dengan meilhat bagian Chi-square dari selisih antara -2 Log Likelihood sebelum variabel independen masuk, dan sesudah variabel independen masuk

\section{Variable In The Equation}

Variable In The Equation adalah uji signifikansi parameter secara parsial atau dari masing-masing variable yang digunakan.

\section{Hosmer and Lemmeshow Goodness of Fit Test}

Hosmer and Lemmeshow Test sama dengan Goodness of Fit Test yang diukur dengan Chi-square dimana uji ini dilakukan untuk menentukan apakah model yang dibentuk tepat atau tidak.

\section{Nagelkerke R Square}

Nagelkerke $R$ Square digunakan untuk menilai kemampuan variabel independen (profitabilitas, solvabilitas dan ukuran perusahan) dalam menjelaskan variabel dependen (Audit Delay) pada PT. Apexindo Pratama Duta Tbk. Nagelkerke R Square dapat dilihat melalui tabel Model Summary.

\section{HASIL PENELITIAN}

Tabel 1.

Hasil uji omnibus

\begin{tabular}{llccr}
\hline \multicolumn{5}{c}{ Omnibus Tests of Model Coefficients } \\
\cline { 2 - 5 } & & Chi-square & df & Sig. \\
\hline \multirow{2}{*}{ Step 1 } & Step & 3,440 & 3 &, 329 \\
\cline { 2 - 5 } & Block & 3,440 & 3 &, 329 \\
\cline { 2 - 5 } & Model & 3,440 & 3 &, 329 \\
\hline
\end{tabular}

Sumber: Hasil Pengolahan Data (2019)

Hasil dari selisih -2 Log Likelihood terdapat pada kolom Chi-square dengan signifikansi sebesar 0,329 yang artinya lebih besar dari $\alpha(0,05)$ maka H0 diterima atau 
variabel bebas secara bersama-sama tidak mempengaruhi model, dan tolak $\mathrm{H} 1$ atau variabel bebas secara bersama-sama mempengaruhi model.

Tabel 2

Hasil uji Nagelkerke R Square

\begin{tabular}{|c|c|c|c|c|c|c|c|}
\hline \multicolumn{8}{|c|}{ Variables in the Equation } \\
\hline & & $\mathrm{B}$ & S.E. & Wald & df & Sig. & $\operatorname{Exp}(B)$ \\
\hline \multirow{7}{*}{$\begin{array}{l}\text { Step } \\
1^{\mathrm{a}}\end{array}$} & Profitabilita & 1,01 & 5,36 & ,036 & 1 & 850 & 2,753 \\
\hline & $\mathrm{s}$ & 3 & 7 & & & & \\
\hline & Solvabilitas & ,228 &, 724 & ,099 & 1 &, 753 & 1,256 \\
\hline & Ukuran & ,000 &, 000 & ,050 & 1 &, 824 & 1,000 \\
\hline & Perusahaan & & & & & & \\
\hline & Constant & 90,4 & 434 & 043 & 1 & ,835 & $1,880 \mathrm{E}+$ \\
\hline & & 32 & 693 & & & & 39 \\
\hline
\end{tabular}

a. Variable(s) entered on step 1: Profitabilitas, Solvabilitas, Ukuran Perusahaan.

Sumber: Hasil Pengolahan Data (2019)

Berdasarkan tabel di atas dapat diketahui nilai dari masing-masing variabel yaitu ada pada kolom Sig. Pada variabel profitabilitas terdapat nilai Sig sebesar 0,850 lebih besar dari $\alpha(0,05)$ yang artinya $\mathrm{H} 0$ diterima atau variabel bebas tidak mempengaruhi model dan tolak H1. Pada variabel solvabilitas terdapat nilai Sig sebesar 0,753 lebih besar dari $\alpha(0,05)$ yang artinya $\mathrm{H} 0$ diterima atau variabel bebas tidak mempengaruhi model dan H1 ditolak. Dan pada variabel ukuran perusahaan terdapat nilai Sig sebesar 0,835 lebih besar dari $\alpha(0,05)$ yang artinya $\mathrm{H} 0$ diterima atau variabel bebas tidak mempengaruhi model dan $\mathrm{H} 1$ ditolak.

\section{PEMBAHASAN}

Didirikan pada tahun 1984, PT Apexindo Pratama Duta Tbk (“Apexindo"/"Perseroan") merupakan satu-satunya perusahaan Indonesia yang bergerak di bidang pengeboran lepas pantai dan pengeboran darat untuk industri minyak, gas, panas bumi dan coal bed methane. Dengan armada yang terdiri dari tujuh rig lepas pantai (3 Jack-Up dan 4 Swamp Barges), delapan rig darat dan satu kapal FPSO yang semuanya berkualitas tinggi dan terpelihara baik, Apexindo telah bekerja untuk berbagai klient, termasuk beberapa perusahaan energi terkemuka seperti Total E\&P Indonesie, Chevron, Pertamina, VICO Indonesia, dan Santos. 
Adapun Visi Perusahaan ialah Kontraktor pengeboran kelas dunia dengan kualitas layanan tanpa kompromi. Sedangkan Misi perusahaan adalah memelihara standar Safety, Health, and Environment (SHE) yang tinggi untuk memastikan keselamatan dan kesejahteraan karyawan dan lingkungan sekitarnya, memberikan nilai yang maksimal kepada para pemangku kepentingan (stakeholders) dan membawa dampak positif kepada masyarakat dan lingkungan dan memiliki sumber daya manusia dengan kualitas dan kompetensi standar dunia.

Berdasarkan hasil analisa data didapatkan nilai $\rho$ value semua variabel independen diatas 0.05 yang berarti tidak mempengaruhi variabel dependen dalam hal ini profitabilitas, solvabilitas dan ukuran perusahaan tidak menyebabkan Audit Delay pada perusahaan.

Profitabilitas dapat menggabarkan bagaimana perusahaan bisa menghasilkan laba dengan modal yang dimiliki. Jika sebuah perusahaan dapat menghasilkan laba, maka perusahaan tersebut bisa menarik perhatian para investor untuk menanamkan dananya sebab perusahaan terbuka atau Go Public selalu diawasi oleh para investor. Para investor biasanya cermat dalam meneliti profit perusahaan. Adapun Solvabilitas ini bagaimana sebuah perusahaan dalam memenuhi kewajiban-kewajibannya baik dalam jangka pendek maupun jangka panjang. Jika nilai profitabilitas rendah maka dalam menganalisa laporan keuangan harus lebih berhati-hati dan membutuhkan waktu yang lebih atau sebaliknya. Sama halnya dengan jika nilai solvabilitas perusahaan besar auditor juga harus berhati-hati dalam menganalisa keuangan, karena nilai beban yang didapat perusahaan besar juga sebaliknya.

\section{SIMPULAN}

Berdasarkan dari hasil analisis yang telah dilakukan, maka dapat disimpulan bahwa profitabilitas, solvabilitas dan ukuran perusahaan tidak menyebabkan Audit Delay pada PT. Apexindo Pratama Duta Tbk. Dan hasil dari perhitungan secara parsial atau dari masing-masing variabel menunjukan tidak berpengaruh atau tidak menyebabkan Audit Delay. 


\section{DAFTAR PUSTAKA}

Astuti, D. (2004). Manajemen Keuangan Perusahan. Jakarta: Ghalia Indonesia.

Brigham \& Houston. (2010). Dasar-dasar Manajemen Keuangan. Buku Satu Edisi Kedua. Diterjemahkan Oleh Ali Akbar Yulianto. Jakarta: Salemba Empat.

Juniati, E. (2016). Analisis Faktor Yang Mempengaruhi Keterlambatan Penyampaian Laporan Keuangan Pada Perusahaan Pertambangan Yang Terdaftar Di Bursa Efek Indonesia Periode Tahun 2011-2013. Jurnal Ekonomi. 3, (1).

Malinda D., A. (2015). Analisis Faktor-faktor yang mempengaruhi Audit Delay (Studi Empiris pada Perusahaan Pertambangan yang Terdaftar di Bursa Efek Indonesia tahun 2008-2013). Skripsi. Tidak Diterbitkan. Fakultas Ekonomi. Universitas Negeri Yogyakarta: Yogyakarta.

Pemerintah Indonesia. Peraturan Otoritas Jasa Keuangan Nomor 29 Tahun 2016 Tentang Laporan Tahunan Emiten atau Perusahaan Publik. www.ojk.go.id/id/kanal/pasar-modal/regulasi/peraturanojk/Documents/Pages/POJK-Laporan-Tahunan-Emiten-PerusahaanPublik/POJK-Laporan-Tahunan.pdf (Diakses 05 Maret 2019)

Pemerintah Indonesia. Peraturan Otoritas Jasa Keuangan Nomor 04 Tahun 2017 Tentang Bentuk dan Isi Prospektus Dalam Rangka Penawaran Umum dan Penambahan Modal Dengan Memberikan hak Memesan Efek Terlebihdahulu Oleh Emiten Dengan Aset Skala Kecil Atau Emiten Dengan Skala Menengah. www.ojk.go.id/id/kanal/pasarmodal/regulasi/peraturan-ojk/Pages/POJK-Nomor-54-POJK.04-2017.aspx

(Diakses 05 Maret 2019)

Respati, N., W., T. (2004). Faktor-faktor Yang Berpengaruh Terhadap Ketepatan Waktu Pelaporan Keuangan (Studi Empiris di Bursa Efek Jakarta). Jurnal Maksi. 4 (1). 71. 